\title{
A universalização da Educação Básica no Brasil: um longo caminho
}

\section{Universalization of Basic Education in Brazil: a long path}

\section{Universalización de la Educación Básica en Brasil: un largo camino}

\author{
Jouiles Uitório Trevisol ${ }^{\wedge}$ \\ Universidade Federal da Fronteira Sul de Chapecó, Pró-reitor de Pesquisa e Pós-graduação \\ Lizeu Mazzioni² \\ Rede de ensino municipal de Chapecó, Professor; Federação dos Trabalhadores Municipais \\ de Santa Catarina, Presidente
}

Resumo: $\bigcirc$ presente artigo resulta de uma extensa pesquisa bibliográfica e documental desenvolvida entre agosto de 2014 e novembro de 2016 cujo propósito foi compreender a construção dos direitos à educação no Brasil e a universalização da educação básica. De natureza histórico-sociológica, o estudo demonstra que as raízes oligárquicas do Estado, assim como a cultura escravocrata e autoritária da sociedade fizeram tardar ao máximo a positivação dos direitos à educação pública e gratuita. A instrução primária, com duração de 2 a 5 anos, foi estruturada a partir de 1920 mediante as reformas estaduais. A escolaridade mínima obrigatória de 8 anos foi estabelecida somente em 1971 (Lei n. 5.692); a de 9 anos, em 2006 (Lei n. 11.274 ) e a de 14 anos (dos 4 aos 17 anos de idade, envolvendo a educação básica, inclusive para os jovens e adultos que não tiveram acesso na idade própria) em 2009 (Emenda Constitucional n. 59). A despeito de o Estado brasileiro ter reconhecido a educação como um direito social na década de 1930, foi somente em 1988 que o ensino obrigatório foi assumido pela Constituição como um direito público subjetivo. Ao aprovar esse princípio, a Constituição introduziu um importante instrumento jurídico de controle da atuação do poder estatal. Trata-se de uma importante inovação na medida em que ficam estabelecidas algumas situações nas quais o Poder Público

Pós-doutor pelo Centro de Estudos Sociais da Universidade de Coimbra, Portigal; Doutor em Sociologia pela Universidade de São Paulo.

2 Mestre em Educação pela Universidade Federal da Fronteira Sul; Especialista em Esporte Escolar (Faculdades Reunidas de Administração, Ciências Contábeis e Ciências Econômicas de Palmas). 
tem o dever de assegurar e fazer em benefício do interesse individual do cidadão.

Palavras-chave: Política educacional. Universalização da educação básica. Direitos sociais. Cidadania.

Abstract: This article results from an extensive bibliographical and documentary research developed between August 2014 and November 2016, whose purpose was to understand the construction of the rights to education in Brazil and the universalization of basic education. Of historical and sociological nature, the study demonstrates that the oligarchic roots of the State, as well as the slave-owning and authoritarian culture of society, delayed to the maximum the positivation of the rights to free public education. The primary education, lasting from 2 to 5 years, was structured from 1920 through the state reforms. Minimum compulsory schooling of 8 years was established only in 1971 (Law 5.692); of 9 years, in 2006 (Law 11,274) and 14 years (from 4 to 17 years old, involving basic education, including for young people and adults who did not have access to their own age) in 2009 (Constitutional Amendment 59 ). Although the Brazilian State recognized education as a social right in the 1930s, it was only in 1988 that compulsory education was assumed by the Constitution as a subjective public right. In approving this principle, the Constitution introduced an important legal instrument to control the performance of state power. This is an important innovation in the means that some situations are established in which the public power has the duty to ensure and do, to the benefit of the individual's interest of the citizen.

Keywords: Educacional policies. Universalization of basic education. Social rights. Citizenship.

Resumen: El presente artículo resulta de una extensa investigación bibliográfica y documental desarrollada entre agosto de 2014 y noviembre de 2016 cuyo propósito fue comprender la construcción de los derechos a la educación en Brasil y la universalización de la educación básica. De carácter histórico-sociológico, el estudio demuestra que las raíces oligárquicas del Estado, así como la cultura esclavócrata y autoritaria de la sociedad, tardaron al máximo la positivación de los derechos a la educación pública y gratuita. La instrucción primaria, de duración de 2 a 5 años, fue estructurada a partir de 1920 mediante las reformas estatales. La escolaridad mínima obligatoria de 
8 años fue establecida solamente en 1971 (Ley 5.692); la de 9 años, en 2006 (Ley 11.274) y la de 14 años (de los 4 a los 17 años de edad, involucrando la educación básica, incluso para los jóvenes y adultos que no tuvieron acceso a la edad propia) en 2009 (Enmienda Constitucional 59). A pesar de que el Estado brasileño reconoció la educación como un derecho social en la década de 1930, fue sólo en 1988 que la enseñanza obligatoria fue asumida por la Constitución como un derecho público subjetivo. Al aprobar ese principio, la Constitución introdujo un importante instrumento jurídico de control de la actuación del poder estatal. Se trata de una importante innovación en la medida en que quedan establecidas algunas situaciones en que el Poder Público tiene el deber de asegurar y hacer, en beneficio del interés individual del ciudadano.

Palabras clave: Políticas educacionales. Universalización de la educación básica. Derechos sociales. Ciudadanía.

\section{INTRODUÇÃO}

Todo ser humano tem direito à instrução. A instrução será gratuita, pelo menos nos graus elementares e fundamentais. A instrução elementar será obrigatória. (ORGANIZAÇÃO DAS NAÇÕES UNIDAS, 2008).

No início deste século, em 2004, o cientista político José Murilo de Carvalho publicou uma obra que serve de referência e inspiração ao presente artigo. No livro intitulado Cidadania no Brasil. O longo caminho, Carvalho mergulha na história brasileira com o propósito de compreender a longa, tortuosa e conflitiva construção dos direitos sociais, entre os quais o da educação. Na parte inicial, o autor faz uma observação fundamental, precedida pelo destaque de que esse aspecto tem sido pouco considerado nos estudos sobre cidadania, inclusive pelo próprio Marshall (1967). Segundo o autor, a educação [...] "tem sido historicamente um pré-requisito para a expansão dos outros direitos." (CARVALHO, 2014, p. 17). Educação e cidadania são, nesse sentido, dimensões complementares e interdependentes. $\bigcirc$ avanço de uma é pré-condição para o desenvolvimento da outra. 
A afirmação de que a educação é um pré-requisito para a expansão dos direitos de cidadania, ainda que não contenha nenhum ineditismo, é suficientemente forte para ser assumida como tese central deste artigo, a partir da qual procuramos desenvolver uma análise sobre os avanços e as contradições presentes no processo de universalização da educação básica. De natureza histórico-sociológica, este estudo é particularmente importante dado o fato de que no Brasil o Estado assumiu tardiamente a educação como um direito social e como direito público subjetivo. As raízes absolutistas e oligárquicas do Estado, assim como a cultura escravocrata e autoritária da sociedade fizeram tardar ao máximo a positivação dos direitos à educação pública e gratuita. As elites agrárias, em particular, foram refratárias e resistiram até onde foi possível às pressões pela criação de escolas públicas destinadas aos mais pobres, especialmente aos negros e às meninas. É revelador, nesse sentido, o ano da criação do Ministério dos Negócios da Educação e Saúde Pública. Apenas em 1930, logo após o fim da República Velha, o Governo federal reconheceu a educação como tema nacional e tomou as primeiras medidas para expandir o sistema público de ensino e organizar a contratação de professores e a carreira docente. Foram necessários quase cinco séculos para aprovar, na Constituição de 1988, que a educação é um direito público subjetivo.

No presente estudo, alicerçado em extensa pesquisa bibliográfica e documental realizada entre agosto de 2014 e novembro de 2016, pretendeuse compreender a universalização da educação básica no Brasil no contexto dos processos de expansão dos direitos de cidadania. $\bigcirc$ tardio compromisso do Estado brasileiro com a educação e a resistência em assumi-la como direito público subjetivo não estão desassociados do lento e tortuoso processo de construção da democracia e dos direitos de cidadania (civis, políticos, sociais, econômicos e culturais). 


\section{OS PRIMÓRDIOS: A EDUCAÇÃO COMO PRIUILÉGIO DAS ELITES}

A noção de direitos no Brasil é bastante tardia. $\bigcirc$ princípio de que os indivíduos são cidadãos e, portanto, portadores de direitos tardou a ganhar presença e raízes em nossa cultura e em nossas instituições. Por longos séculos a escravidão e a posse altamente concentrada de terra ofereceram os pilares para a organização social, política e econômica da sociedade e para a reprodução de uma estrutura social autoritária e desigual (CHAUI, 2000; CARVALHO, 2014; RIBEIRO, 2013). Não sem razões, o Brasil foi o último país da América Latina a abolir a escravidão. Como tão bem destaca Carvalho (2014, p. 2324), os portugueses construíram um enorme país dotado de unidade territorial, linguística, cultural e religiosa, porém deixaram "[...] uma população analfabeta, uma sociedade escravocrata, uma economia monocultural e latifundiária, um Estado absolutista. À época da independência, não havia cidadãos brasileiros, nem pátria brasileira."

As duas mudanças políticas fundamentais do século XIX não alteraram a estrutura da sociedade brasileira. A declaração de Independência em 1822 e a proclamação da República em 1889 deixaram intactos o autoritarismo e os mecanismos de reprodução das desigualdades. As elites não incorporaram a agenda dos direitos de cidadania nos processos políticos que resultaram na criação do Estado brasileiro e, mais adiante, na implantação da República. Podese afirmar que até 1930 o campo dos direitos, sobretudo os civis, os políticos e os sociais, não havia sido incorporado pelo Estado como dimensão estruturante de sua relação com a sociedade. Foi o Governo Vargas que introduziu, ainda que de forma tímida e parcial, os primeiros deveres do Estado para com os seus cidadãos. Essa refundação da ordem política se realiza sob o primado de que os indivíduos, em vez de súditos, são cidadãos portadores de direitos (e não apenas de deveres e obrigações). A partir de 1930, são instituídas, portanto, novas relações jurídicas e obrigações comuns entre Estado e indivíduos e são lançadas as bases para o surgimento no Brasil tanto do "Estado-nação" quanto do "Estado de direito" (DUARTE, 2004, p. 113-114). 
Isso permite compreender por que a educação brasileira se manteve, por longos séculos, sendo concebida e tratada como um bem privado e um privilégio restrito aos grupos sociais mais abastados (GOMES, 2010, 2013). Pode-se afirmar que a criação do Ministério dos Negócios da Educação e Saúde Pública (1930) e o movimento dos Pioneiros da Educação Nova (1932) marcam uma mudança qualitativa na forma como o Estado e a sociedade compreendem a educação. Novas concepções e políticas inseriram, gradativamente, a educação como um bem público e um direito social. Pela primeira vez, de forma mais nítida, o cidadão é instituído como titular de um direito, e o Estado, tornado responsável pela sua implementação, via políticas públicas que promovem a laicidade e o princípio da gratuidade. Ao reconhecer e incorporar a educação como um direito social, o Estado-nação se conecta à cidadania.

Em 1929, ano anterior à criação do Ministério da Educação, cerca de $65 \%$ dos brasileiros de 15 ou mais anos de idade eram analfabetos (INSTITUTO NACIONAL DE ESTUDOS E PESQUISAS EDUCACIONAIS ANÍSIO TEIXEIRA, 2003b, p. 6). As matrículas do ensino primário correspondiam a 35\% das crianças de 7 a 12 anos (NAGLE, 2009, p. 314; IBGE, 2006b, p. 1). Os números desse período refletiam o que o País havia feito em seus primeiros 400 anos de história, considerando que a Coroa portuguesa instituiu o primeiro Governo Geral no Brasil em 1549. $\bigcirc$ governador designado, Tomé de Souza, assumiu a função acompanhado pelo padre Manuel da Nóbrega e mais quatro freis e dois irmãos jesuítas (SAVIANI, 2013), cujos primeiros atos foram a construção do Colégio dos Meninos de Jesus da Bahia, o Colégio dos Meninos de Jesus de São Vicente e de outras escolas de instrução elementar em Porto Seguro, Ilhéus, Espírito Santo, São Paulo de Piratininga e Rio de Janeiro (GHIRALDELLI JÚNIOR, 1995).

Enquanto parte de uma política de administração da Coroa, a chegada dos padres jesuítas, além de marcar o início da instrução formal no Brasil, pode ser considerada o primeiro ato regulatório da educação brasileira, dele decorrendo uma série de desdobramentos, entre os quais uma delegação de competência conferida à Companhia de Jesus para que cuidasse dos assuntos educacionais na Colônia. As primeiras ações foram implementadas 
sob a égide de um projeto colonizador da Metrópole e de uma estratégia contrarreformista dos jesuítas de catequização e de conversão ao catolicismo.

$\bigcirc$ intento educacional dos padres foi levado adiante com muita tenacidade. No período entre 1549 e 1759 (ano da expulsão dos jesuítas do Brasil) foram criados, segundo Ghiraldelli Júnior (1995, p. 26) mais de 100 estabelecimentos de ensino (colégios, residências, missões, seminários e escolas de ler e escrever). A catequese que, em princípio, constituía o objetivo principal da presença jesuítica no Brasil, foi gradativamente cedendo lugar e importância à educação da elite. Segundo Romanelli (2014, p. 33-36), a obra educativa da Companhia de Jesus se adaptou - e passou a servir - à aristocracia e à elite agrária, que passaram a demandar na Colônia o mesmo conteúdo cultural ministrado na Metrópole. $\bigcirc$ acesso restringiu-se a uma pequena elite, predominantemente composta por meninos brancos e filhos dos senhores de engenhos.

A expulsão dos jesuítas em 1759 desmantelou a pequena estrutura de ensino existente, ficando mantidos apenas os colégios para a formação de sacerdotes e os seminários para a formação do clero secular. À época, apenas 0,1\% da população brasileira frequentava algum tipo de escola (ROMANELLI, 2014). Nenhuma ação substancial foi implementada nas décadas seguintes com o propósito de reorganizar a estrutura de ensino. Apenas a partir de 1808 , com a chegada da Família Real ao Brasil, foram tomadas medidas que visavam instalar as primeiras instituições de ensino técnico e superior. As iniciativas, no entanto, mantiveram e aprofundaram os compromissos em curso nos séculos anteriores. Como observa Romanelli (2014, p. 39):

[...] o aspecto de maior relevância dessas iniciativas foi - fato de terem sido levadas a cabo, com o propósito exclusivo de proporcionar educação para uma elite aristocrática e nobre de que se compunha a corte. A preocupação exclusiva com a criação de ensino superior e o abandono total em que ficaram os demais níveis do ensino demonstraram claramente esse objetivo, com o que se acentuou uma tradição - que vinha da Colônia - a tradição da educação aristocrática. 
Durante a Colônia (1500-1822) a educação ficou a cargo da Companhia de Jesus dos padres jesuítas, que teve como objetivo a conversão e domesticação dos índios ("os gentios") para a Santa Fé Católica, a educação dos filhos da aristocracia e a formação do clero. Sem qualquer política pública de educação durante o Período Colonial, em 1822, quando da independência e formação do Estado brasileiro, 99\% da população continuava analfabeta (GOMES, 2010, p. 215).

A criação do Estado brasileiro em 1822 não implicou mudança substancial na ordem social. $\bigcirc$ ato político que a história consagrou como independência não foi originado de uma revolução ou de um levante popular. A implantação do regime monárquico decorreu de uma negociação interna entre a Família Real e as elites. A grande fazenda e o regime de escravidão, principais alicerces da sociedade colonial, mantiveram-se intactos. A educação, por conseguinte, também não foi incorporada como dimensão estruturante do Império, cujos propósitos fundamentais foram a consolidação da independência, a integridade do território nacional e a continuidade da escravidão. A Constituição de 1824, em seu Art. 179, XXXII, estabeleceu que a instrução primária deveria ser gratuita a todos os cidadãos. $\bigcirc$ avanço, no entanto, ficou limitado a um grupo seleto de homens brancos e ricos, dado o fato que as mulheres e os escravos não eram reconhecidos como cidadãos (BRASIL, 1824). De acordo com Ghiraldelli Júnior (1995, p. 28), o Império estruturou o ensino em três níveis: primário, secundário e superior:

[...] O primário era "escola de ler e escrever", que ganhou um incentivo da Corte e aumentou suas disciplinas consideravelmente. $\bigcirc$ secundário se manteve dentro do esquema das "aulas régias", mas ganhou uma divisão em disciplinas, principalmente nas cidades de Pernambuco, Minas Gerais e Rio de Janeiro.

Três anos depois, em 1827, a Assembleia Geral do Império aprovou o que pode ser considerada a primeira lei nacional de educação. Ela criou o ensino primário no Brasil. Aprovada em 15 de outubro, a Lei Imperial (BRASIL, 1827), em seu Art. 1², determinou a criação "de escolas de primeiras letras em todas as cidades, vilas e lugares mais populosos do Império." Além disso, 
estabeleceu o método a ser adotado (método Lancaster de ensino), ${ }^{3}$ assim como o currículo. $\bigcirc$ Art. $6^{\circ}$ fixou as seguintes diretrizes curriculares:

Os professores ensinarão a ler, escrever, as quatro operações de aritmética, prática de quebrados, decimais e proporções, as noções mais gerais de geometria prática, a gramática de língua nacional, e os princípios de moral cristã e da doutrina da religião católica e apostólica romana, proporcionados à compreensão dos meninos; preferindo para as leituras a Constituição do Império e a História do Brasil. (BRASIL, 1827).

A despeito da ousadia em seus propósitos, a Lei esbarrou em sérias limitações estruturais. De acordo com Araújo (2002, p. 4), em 1832 haviam, em todo o Império, apenas

162 escolas de meninos e 18 de meninas; estas escolas estavam estabelecidas no Rio de Janeiro e na província do mesmo nome e também nas províncias da Bahia, Pernambuco, Rio Grande do Norte, Piauí, Pará, Mato Grosso, Goiás e S. Pedro do Rio Grande do Sul; sobre estas 180 escolas, havia ao menos 40 nas quais o lugar do professor estava vacante, e deste número, 8 eram escolas de meninas. Havia, pois, em todo o Brasil, 10 escolas para o sexo feminino.

Em 1834 foi aprovado o Ato Adicional de 1834, por meio do qual o Império descentralizou para as províncias um conjunto de direitos e deveres, entre os quais o da educação. Em seu Art. 10, ficou definido que:

Compete ás mesmas Assembléas legislar:

[...] $\$ 2^{\circ}$ Sobre instrucção publica e estabelecimentos proprios a promovel-a, não comprehendendo as faculdades de Medicina, os Cursos Juridicos, Academias actualmente

\footnotetext{
3 Segundo Araújo (2002, p. 2), a Lei Imperial de 15 de outubro 1827 estabeleceu que a "escolarização primária deveria fazer-se reger pelo método lancasteriano de ensino mútuo, por ele consagrar princípios inovadores e por dever a difusão da instrução primária atingir simultaneamente um grande número de escolares, sob a responsabilidade de um mestre ou uma mestra, auxiliados por monitores ou decuriões, com deveres de ensinar e tomar lições ou mesmo acompanhar as aulas das turmas menos adiantadas [...]"
} 
existentes e outros quaesquer estabelecimentos de instrucção que para o futuro forem creados por lei geral. (BRASIL, 1834).

O Ato Adicional de 1834 instituiu no Brasil a dualidade de sistemas de ensino. A instrução primária e secundária ficou sob a responsabilidade das Províncias (Estados) e a educação superior sob os cuidados da União. A falta de recursos foi um dos principais entraves para a expansão das escolas e das matrículas. $O$ ensino secundário ficou nas mãos da iniciativa privada, enquanto o ensino primário "[...] foi relegado ao abandono, com pouquíssimas escolas, sobrevivendo às custas do sacrifício de alguns mestres-escola, que, destituídos de habilitação para o exercício de qualquer profissão rendosa, se viam na contingência de ensinar." (ROMANELLI, 2014, p. 40). Os cerca de 250.000 alunos em 1888 (de uma população estimada em 14 milhões de habitantes) encontravam-se distribuídos em escolas primárias, liceus provinciais, colégios particulares e cursos normais. Ao final do regime imperial, como observa Souza (2008, p. 40), "[...] o tempo de duração do curso primário ainda não havia se regularizado, acompanhando mais o ritmo da aprendizagem dos alunos do que uma determinação externa, e os exames eram tidos como uma inovação recente." Em 1872, cerca de 16\% da população brasileira era alfabetizada (CARVALHO, 2014, p. 28).

A dualidade de sistemas foi aprofundada com a proclamação da República. Em 1890, por meio do Decreto n. 346, o presidente Deodoro da Fonseca criou a Secretaria de Estado dos Negócios da Instrução Pública, Correios e Telégrafos para cuidar da educação do País (ROMANELLI, 2014). A Constituição de 1891 instituiu o sistema federativo, introduziu a laicidade nos estabelecimentos públicos (principal inovação) e consagrou a descentralização do ensino, atribuindo aos Estados a competência de gerir o ensino primário e o ensino profissional (principalmente as escolas normais para as moças e as escolas técnicas para os rapazes). À União coube, conforme disposto no Art. 35, itens $3^{\circ}$ e $4^{\circ}$, criar e controlar a instrução superior em toda a nação, bem como criar e controlar o ensino secundário acadêmico e a instrução em todos os níveis do Distrito Federal (BRASIL, 1891). 
A aclamada "res pública" poucos avanços produziu no campo da cidadania. A despeito de prometida pela propaganda republicana desde 1870, a escola pública pouco foi expandida. Em 1920, cerca de 75\% da população em idade escolar ou mais era analfabeta (GHIRALDELLI JÚNIOR, 1995). Controlada pelas elites agrárias, a nascente República não conferiu prioridade à educação. A responsabilidade foi transferida aos Estados, que, no geral, não dispunham de condições para implementar as redes de ensino (NAGLE, 2009). Múltiplas diferenciações foram se configurando no processo de expansão do ensino. Em 1922, o número de matrículas nas escolas primárias (1.030.752) correspondia a cerca de 29\% da população escolar (NAGLE, 2009). Os ritmos da expansão, conforme observa Souza (2008, p. 47):

[...] foram muito desiguais do ponto de vista regional e a estratificação atingiu também a rede escolar dos estados, estabelecendo diferenças nas condições materiais das escolas, nos tipos de instituições educativas (grupos, escolas isoladas e reunidas) e no ensino ministrado, tendo em vista a localização das escolas (na zona urbana ou rural, no centro ou na periferia das grandes cidades).

A omissão do Governo federal ensejou, a partir dos anos 1920, iniciativas pontuais de baixo alcance implementadas nos diferentes estados. Em 1920, Sampaio Dória promoveu uma reforma do ensino no Estado de São Paulo, sucedida pelo Estado do Ceará em 1922 e 1923; pelo Rio Grande do Norte, entre 1925 e 1928; pelo Distrito Federal, entre 1922 e 1926; por Pernambuco, em 1928; pelo Paraná, entre 1927 e 1928; por Minas Gerais, entre 1927 e 1928, e pela Bahia, em 1928 (ROMANELLI, 2014, p. 130). As reformas regionais introduziram configurações muito distintas para a educação, além de estruturarem sistemas de ensino muito desiguais em termos de infraestrutura e qualidade. ${ }^{4}$ Os governos estaduais, em geral, não construíam as escolas, atribuição que ficava sob a responsabilidade dos municípios ou das elites locais. O Estado fornecia os livros oficiais (os únicos permitidos) e se responsabilizava pelo pagamento do professor, devendo este ser normalista ou formado pela

\footnotetext{
4 Uma descrição e análise bastante detalhada sobre as reformas estaduais introduzidas nos anos 1920 é feita por Nagle (2009, p. 221-239).
} 
Escola Normal da capital. As escolas podiam aceitar meninas e meninos, com turno de aulas entre nove da manhã e 14 horas (GHIRALDELLI JÚNIOR, 1995).

Conforme é possível observar na Tabela 1, as reformas estaduais, a despeito de suas limitações, contribuíram para um aumento do número de matrículas do ensino primário geral (7 a 12 anos), passando de 1.250.729 matrículas em 1920 para 2.057.616, em 1929, ou seja, de 24,6\% para 35,5\% do total das crianças em idade escolar da época (NAGLE, 2009; IBGE 2006a).

Tabela 1 - Matrículas do ensino primário no Brasil entre 1872 e 1930

\begin{tabular}{|c|c|c|c|c|c|}
\hline Ano & 1872 & 1884 & 1907 & 1920 & 1929 \\
\hline População de 7 a 12 anos & 1.468 .037 & 1.793 .941 & 3.607 .765 & 5.091 .096 & 5.793 .717 \\
\hline $\begin{array}{l}\text { Ensino Primário Geral (7 a } \\
12 \text { anos) }\end{array}$ & 139.321 & 232.598 & 638.378 & 1.250 .729 & 2.057 .616 \\
\hline $\begin{array}{l}\text { Matrículas primárias em } \\
\text { percentual do total de } \\
\text { crianças de } 7 \text { a } 12 \text { anos }\end{array}$ & $9,5 \%$ & $13,0 \%$ & $17,7 \%$ & $24,6 \%$ & $35,5 \%$ \\
\hline
\end{tabular}

Fonte: elaborada com base nos dados disponíveis em IBGE (2006c, p. 1), IBGE (2006b, p. 1) e Nagle (2009, p. 314).

\section{A REUOLUÇÃO DE 1930 E A ESCOLA NOUA: A EDUCAÇÃO COMO DIREITO SOCIAL}

Na década de 1920 o desequilíbrio entre a demanda social por educação e a limitada oferta de ensino passou a ser tematizada por diversos movimentos e setores da sociedade. As Ligas Nacionalistas e as reformas estaduais coordenadas por destacados educadores, como Sampaio Dória, Lourenço Filho, José Augusto, Carneiro Leão, Francisco Campos, Fernando Azevedo e Anísio Teixeira, assumiram a escolarização como dimensão fundamental para o desenvolvimento do País. Em 1924 surge a Associação Brasileira de Educação (ABE), entidade que passa a organizar várias conferências nacionais de educação e a aglutinar inúmeros educadores dispostos a enfrentar a hegemonia das escolas católicas, claramente avessas à tese de que a educação devia ser pública, gratuita e laica (GHIRALDELLI JÚNIOR, 1995; ROMANELLI, 2014; SAVIANI, 2013). Em 
1926 a responsabilidade estatal sobre a escolarização foi pauta da revisão da Constituição de 1891, podendo ser considerado o ano-referência dos debates sobre o papel estratégico do Estado, particularmente da União, na difusão e na consolidação da escola pública (FREITAS; BICCAS, 2009).

Em 1930, ano em que Vargas chegou ao poder, já eram fortes as teses de que o Governo federal deveria assumir a educação como um direito social e como uma política de Estado destinada a garantir a escola pública, laica e gratuita a todos. Poucas semanas após a tomada do poder, Vargas assinou - Decreto n. 10.402, de 14 de novembro de 1930, criando o Ministério dos Negócios da Educação e Saúde Pública. Em 1931, por meio do Decreto n. 19.850, foi criado o Conselho Nacional de Educação. Além disso, determinou que os Estados deveriam investir 10\%, no mínimo, das receitas na instrução primária (INSTITUTO NACIONAL DE ESTUDOS E PESQUISAS EDUCACIONAIS ANÍSIO TEIXEIRA, 1997, p. 126-130). A mensagem presidencial de Vargas, enviada à Assembleia Constituinte em 1933, é bastante enfática quanto aos desafios, em um momento em que o ensino primário abrangia 2.020.931 matrículas, 20.918 escolas públicas, 7.632 escolas particulares e 54.337 professores (INSTITUTO NACIONAL DE ESTUDOS E PESQUISAS EDUCACIONAIS ANÍSIO TEIXEIRA, 1997, p. 127-128):

[...] Nas condições atuais, a capacidade teórica do nosso aparelho escolar, para o ensino primário, não pode ir além de 10\% da massa demográfica. Segundo o cálculo de 40 milhões para a nossa população, deveríamos contar com 4 milhões de educandos [...] De modo mais frisante, pode-se determinar que, entre 1.000 brasileiros aptos para receberem a educação cultural elementar, 513 não ingressam na escola e dos 487 restantes 110 matriculamse, mas não freqüentam os cursos; 178 freqüentam o primeiro ano de estudos, não chegando bem a ler; 85 freqüentam somente até o segundo ano, alfabetizandose muito superficialmente; 84 vão um pouco além, mas não chegam a concluir os estudos; e apenas 30 adquirem integralmente a instrução elementar comum, assim mesmo em condições de grande desigualdade de aproveitamento e reconhecida eficiência, atinente à profundidade do ensino, que não se prolonga, em média, além de três anos, com todas as lacunas pedagógicas da maior parte das escolas do interior. [...] Diante da realidade destas cifras, não cabem conjeturas otimistas. Não é possível ensinar 
sem escolas. $\bigcirc$ número das existentes está muito aquém das necessidades. $\bigcirc$ problema da educação do povo continua a ser, ainda e sempre, o nosso magno problema. No momento em que se vai reorganizar a vida política do país, torna-se de evidente oportunidade lembrálo e trazê-lo à consideração da Assembleia Nacional Constituinte, que, certamente, procurará dar-lhe solução completa e definitiva. Não temos o direito de postergar indefinidamente essa solução. A dolorosa verdade aí está, desdobrada perante a nação, desafiando, com toda a trama da sua complexidade angustiante, a nossa maior soma de boa vontade e energia. (INSTITUTO NACIONAL DE ESTUDOS E PESQUISAS EDUCACIONAIS ANÍSIO TEIXEIRA, 1997, p. 127-128).

Os debates sobre as políticas educacionais se intensificaram, sobretudo entre os grupos conservadores católicos e o movimento dos Pioneiros da Escola Nova, que defendiam a escola pública, ${ }^{5}$ e um terceiro grupo, que defendia a educação eugênica. ${ }^{6}$ A Constituição de 1934 reflete essas disputas, sendo a primeira na história do Brasil a assumir a universalização como política de Estado. Em seus Arts. 149 e 150, estabelece que:

\begin{abstract}
Art. 149 - A educação é direito de todos e deve ser ministrada, pela família e pelos Poderes Públicos.

[...]

Art. 150 - Compete à União: a) fixar o plano nacional de educação, compreensivo do ensino de todos os graus e ramos, comuns e especializados; e coordenar e fiscalizar a sua execução, em todo o território do País; [...] c) organizar e manter, nos Territórios, sistemas educativos apropriados aos mesmos; d) manter no Distrito Federal ensino secundário e complementar deste, superior e universitário; e) exercer ação supletiva, onde se faça necessária, por deficiência de iniciativa ou de recursos e estimular a obra educativa em todo o País, por meio de estudos, inquéritos, demonstrações e subvenções. Parágrafo único. $\bigcirc$ plano nacional de educação constante de lei federal [...] obedecerá às seguintes normas: a) ensino primário integral gratuito e de frequência obrigatória extensivo aos adultos; b) tendência à gratuidade do ensino educativo ulterior ao primário, a fim de o tornar mais acessível. (BRASIL, 1934).
\end{abstract}

\footnotetext{
5 Para uma compreensão do conteúdo e da importância do Manifesto dos Pioneiros da Educação Nova de 1932, ver a íntegra do documento (AZEVEDO, 2010).

6 Uma análise mais detalhada sobre os movimentos em defesa da escola eugênica no Brasil é desenvolvida por Schneider e Meglhioratti (2012) e Mazzioni (2016).
} 
Poucos anos depois, na Constituição que originou o "Estado Novo", Vargas fez recuar os compromissos do Estado com a gratuidade da escola pública, cedendo às pressões advindas dos grupos conservadores que defendiam o pagamento e, alguns, a educação eugênica. A obrigatoriedade do ensino primário é mantida, porém é instituída a cobrança para quem não comprovar insuficiência de recursos. $\bigcirc$ Art. 130 estabelece que no ato da matrícula "[...] será exigida aos que não alegarem, ou notoriamente não puderem alegar escassez de recursos, uma contribuição módica e mensal para a caixa escolar." (BRASIL, 1937).

Aspectos da Constituição de 1937 foram retomados e aprofundados a partir de 1942, por meio das Leis Orgânicas do Ensino (Decretos-Leis) que integraram a Reforma Capanema. Pode-se afirmar que as Leis Orgânicas instituíram o primeiro sistema educacional no País, de "caráter elitista e conservador", estruturado em quatro níveis: primário, secundário, profissional e superior (GHIRALDELLI JÚNIOR, 1995, p. 80). Os Decretos-Leis introduziram mudanças no ensino secundário e estruturaram o ensino profissional e o comercial, criando o Sistema Nacional de Aprendizagem Industrial (Senai), em 1942, e o Serviço Nacional de Aprendizagem Comercial (Senac), em 1946. modelo público-privado de ensino profissional instituído se ampliou mais adiante com a criação do Serviço Nacional de Aprendizagem Rural (Senar) e o Serviço Nacional de Aprendizagem do Transporte (Senat).

Em 1945, após 15 anos de Vargas no poder, as matrículas do ensino primário haviam saltado de 2.057.616, em 1929, para 3.295.291, em 1945, correspondendo a 45\% das crianças em idade escolar (IBGE, 2006b, 2006d). analfabetismo de pessoas com 15 ou mais anos também reduziu, de 65\%, em 1920, para 56,1\%, em 1940 (INSTITUTO NACIONAL DE ESTUDOS E PESQUISAS EDUCACIONAIS ANÍSIO TEIXEIRA, 2003b, p. 6).

A deposição de Vargas em 1945 reabriu uma série de discussões sobre o futuro da educação. A Constituição de 1946 (BRASIL, 1946) reestabeleceu alguns compromissos do Estado com a universalização da educação e com a escola pública. Definiu que o ensino primário deve ser obrigatório e gratuito nos 
estabelecimentos oficiais (Arts. 166 e 168, II) e ministrado em língua nacional (Art. 168, I). Também reintroduziu a vinculação de receitas à educação e a ajuda pública aos outros níveis de ensino que provassem "[...] falta ou insuficiência de recursos;" (Art. 168, II). O processo de redemocratização reabriu os debates sobre a necessidade de uma reforma educacional.

Em 1948 o Ministério da Educação instituiu uma comissão responsável pela elaboração de um projeto propondo a Lei de Diretrizes e Bases da Educação Nacional (LDB), o qual foi submetido ao Congresso Nacional no mesmo ano. Após muitas discussões, sobretudo entre os defensores da escola pública e as correntes privatistas, o projeto foi aprovado 13 anos depois, em 20 de dezembro de 1961. A primeira Lei de Diretrizes e Bases da Educação Nacional (Lei n. 4.024/61) foi aprovada em um contexto de grande efervescência e entusiasmo quanto ao futuro do País. Os avanços no campo educacional também se faziam sentir, demonstrando uma progressiva expansão de matrículas do ensino primário. $\bigcirc$ analfabetismo entre pessoas de 15 ou mais anos recuou de 56,1\%, em 1940, para 39,7\%, em 1960 (INSTITUTO NACIONAL DE ESTUDOS E PESQUISAS EDUCACIONAIS ANÍSIO TEIXEIRA, 2003b, p. 6). O número de matrículas no ensino primário em relação ao número de crianças de 7 a 12 anos cresceu de 45\%, em 1945, para 78,6\%, em 1966 (ROMANELLI, 2014, p. 69, 85). Segundo a autora, a taxa de frequência escolar de 7 a 12 anos era de 47,51\% em 1940; 63,29\% em 1950 e de 66, 14\% em 1966 (ROMANELLI, 2014, p. 69, 85).

Nos anos seguintes, entre 1961 e 1971, as políticas de universalização da educação básica foram redefinidas várias vezes, cabendo destaque para a Constituição de 1967 e a LDB de 1971. 
Quadro 1 - A universalização nos principais marcos regulatórios da educação brasileira (1961-1971)

\begin{tabular}{|c|c|}
\hline $\begin{array}{l}\text { LDB 1961 (Lei } \\
\text { n. 4.024) }\end{array}$ & $\begin{array}{l}\text { A Lei n. 4.024/6l foi fortemente influenciada pelos defensores do } \\
\text { ensino privado. A obrigatoriedade do ensino foi retirada, ficando } \\
\text { delegada à família a escolha do gênero de educação a ser dado } \\
\text { aos filhos (Art. } 2^{\circ} \text { ) (BRASIL, } 1961 \text { ). Além de não obrigar o Estado a } \\
\text { ofertar o ensino, também abriu exceções, retirando a obrigatorieda- } \\
\text { de da matrícula no ensino primário para os casos de comprovado } \\
\text { estado de pobreza do pai ou responsável; insuficiência de escolas; } \\
\text { matrícula encerrada; doença ou anomalia grave da criança (Art. 30, } \\
\text { § único) (BRASIL, 1961). O Art. } 3^{\circ} \text { retirou do Estado a obrigação de } \\
\text { garantir escola pública. O direito à educação, segundo o referido } \\
\text { artigo, "é assegurado: I- pela obrigação do poder público e pela } \\
\text { liberdade de iniciativa particular de ministrarem o ensino em todos } \\
\text { os graus, na forma de lei em vigor; II - pela obrigação do Estado de } \\
\text { fornecer recursos indispensáveis para que a família e, na falta desta, } \\
\text { os demais membros da sociedade se desobriguem dos encargos da } \\
\text { educação, quando provada a insuficiência de meios, de modo que } \\
\text { sejam asseguradas iguais oportunidades a todos." (Art. } 3^{\circ} \text { ) (BRASIL, } \\
\text { 196l). A LDB de } 1961 \text { manteve a obrigação das empresas industrias, } \\
\text { comerciais e agrícolas com mais de } 100 \text { pessoas de oferecer edu- } \\
\text { cação primária aos filhos dos empregados (Art. 32) (BRASIL, 196l). } \\
\text { Também criou a escola pública paga para o ensino médio e superior. }\end{array}$ \\
\hline $\begin{array}{l}\text { Constituição } \\
\text { de } 1967\end{array}$ & $\begin{array}{l}\text { A Constituição Federal de 1967, promulgada no auge da Ditadura } \\
\text { Militar, tornou obrigatório o ensino de } 7 \text { a } 14 \text { anos e estabeleceu a } \\
\text { sua gratuidade nos estabelecimentos primários oficiais (Art. 168, § 3, } \\
\text { II) (BRASIL, 1967). }\end{array}$ \\
\hline $\begin{array}{l}\text { LDB } 1971 \text { (Lei } \\
\text { n. 5.692) }\end{array}$ & $\begin{array}{l}\text { A LDB de } 1971 \text { introduziu mudanças importantes no que tange à } \\
\text { universalização. Entre outras diretrizes, ampliou o tempo de ensino } \\
\text { obrigatório de } 4 \text { para } 8 \text { anos (já estabelecido na CF de 1967); alterou } \\
\text { a estrutura da educação básica (unificando o ensino primário e o gi- } \\
\text { nasial), dando origem ao ensino de } 1^{\circ} \text { Grau (de } 8 \text { anos obrigatórios); } \\
\text { transformou o colegial em ensino de } 2^{\circ} \text { Grau. No Art. 20, estabe- } \\
\text { lece que "O ensino de } 1^{\circ} \text { grau será obrigatório dos } 7 \text { aos } 14 \text { anos, } \\
\text { cabendo aos Municípios promover, anualmente, o levantamento da } \\
\text { população que alcance a idade escolar e proceder à sua chamada } \\
\text { para matrícula." (BRASIL, } 1971 \text { ). A Lei n. } 5.692 \text { estabeleceu também } \\
\text { a formação mínima dos professores de } 1^{\circ} \text { e } 2^{\circ} \text { Graus, assim como re- } \\
\text { definiu o concurso público para o ingresso de docentes e os respec- } \\
\text { tivos níveis de remuneração nos planos de carreira (Art. 30, 34, } 36 \text { e } \\
\text { 39). Ficou mantida a liberdade de atuação para a iniciativa privada, } \\
\text { fortalecida com o apoio financeiro público. }\end{array}$ \\
\hline
\end{tabular}

Fonte: os autores. 
Apenas no final da década de 1980, como se pode observar na Tabela 2, a taxa de frequência escolar bruta no ensino obrigatório correspondia ao número de crianças dessa faixa etária. Em 1980, as 19,4 milhões de matrículas de $1^{\circ}$ Grau representavam 83\% da população entre 7 e 14 anos (23,3 milhões de crianças); em 1988, as 26,8 milhões de matrículas do $1^{\circ}$ Grau correspondiam a 101\% dos 23,6 milhões das crianças e jovens entre 7 e 14 anos (IBGE, 2006b, p. 1, 2006e, p. 1). A frequência escolar líquida de crianças e jovens de 7 a 14 anos era de 85\% em 1985; 89\% em 1988 e de 96,9\% em 1992 (INSTITUTO NACIONAL DE ESTUDOS E PESQUISAS EDUCACIONAIS ANÍSIO TEIXEIRA, 2003a; IBGE, 2003).

Tabela 2 - Evolução do número de matrículas no ensino primário (fundamental) entre 1929-1988

\begin{tabular}{lllll}
\hline \multicolumn{1}{c}{ Ano } & \multicolumn{1}{c}{1929} & 1966 & \multicolumn{1}{c}{1980} & 1988 \\
& 7 a 12 anos & 7 a 12 anos & 7 a 14 anos & 7 a 14 anos \\
\hline População em idade escolar & 5.793 .717 & 13.607 .118 & 23.353 .586 & 26.600 .667 \\
Ensino primário (fundamental) & 2.057 .616 & 10.695 .391 & 19.384 .642 & 26.821 .134 \\
$\begin{array}{l}\text { Percentual de matrículas } \\
\text { primárias do total de crianças } \\
\text { em idade escolar }\end{array}$ & $35,5 \%$ & $78,6 \%$ & $83 \%$ & $101,11 \%$ \\
\hline
\end{tabular}

Fonte: elaborada com base nos dados disponíveis em IBGE (2006c, p. 1), IBGE (2006b, p. 1), Nagle (2009, p. 314) e Romanelli (2014, p. 85).

A despeito dos avanços no que tange à universalização, o Brasil chegou ao final do século XX ainda com taxas expressivas de analfabetismo (25,9\% em 1980 e 13,6\% em 2000) e percentuais muito baixos de jovens em idade escolar frequentando o ensino médio e superior. A redemocratização do País fez emergir antigos e legítimos anseios por direitos sociais, cidadania e acesso à educação pública e gratuita de qualidade. A Constituição de 1988 foi aprovada nesse contexto, no bojo de um amplo processo de participação social e política, tendo sido definida, desde o início, como a "Constituição Cidadã". 


\section{A CONSTITUIÇÃO FEDERAL DE 1988: A EDUCAÇÃO COMO DIREITO PÚBLICO SUBJETIUO}

Em 1988, pela primeira vez, uma Constituição brasileira assumiu claros compromissos com a erradicação do analfabetismo e com a universalização da educação básica. Concebida como um "Art. 205 [...] direito de todos e dever do Estado e da família" (BRASIL, 1988), a educação é inserida no rol dos direitos sociais a serem promovidos pelo Estado e pela sociedade. Mais adiante, no parágrafo primeiro do Art. 208, o Texto Constitucional estabelece que "o acesso ao ensino obrigatório e gratuito é direito público subjetivo." Ao aprovar esse primado, a Constituição introduziu um importante instrumento jurídico de controle da atuação do poder estatal. Por meio dele os cidadãos (titulares individuais e coletivos) podem constranger judicialmente o Estado a executar o que deve. Trata-se de uma importante inovação na medida em que ficam estabelecidas algumas situações as quais o Poder Público tem o dever de assegurar e fazer. Como destaca Duarte (2004, p. 113):

[...] o direito público subjetivo confere ao indivíduo a possibilidade de transformar a norma geral e abstrata contida num determinado ordenamento jurídico em algo que possua como próprio. A maneira de fazê-lo é acionando as normas jurídicas (direito objetivo) e transformandoas em seu direito (direito subjetivo) [...] Trata-se de uma capacidade reconhecida ao indivíduo em decorrência de sua posição especial como membro da comunidade, que se materializa no poder de colocar em movimento normas jurídicas no interesse individual.

As políticas e diretrizes estabelecidas pela Constituição de 1988 receberam regulamentações específicas nas décadas seguintes e ensejaram importantes políticas públicas destinadas à universalização. 
Quadro 2 - A universalização nos principais marcos regulatórios da educação brasileira (1988-2014)

\begin{tabular}{|c|c|}
\hline $\begin{array}{l}\text { Constituição } \\
\text { de } 1988\end{array}$ & $\begin{array}{l}\text { A CF estabeleceu a obrigatoriedade e a gratuidade para os oito anos do } \\
\text { Ensino Fundamental (até então denominado de } \text { l }^{\circ} \text { Grau) e para os estu- } \\
\text { dantes que não tiveram acesso na idade própria. Definido como "direito } \\
\text { público subjetivo", o Ensino Fundamental passou a ser um dever do Estado, } \\
\text { devendo ser ofertado de forma gratuita (Art. 208, § 1) (BRASIL, 1988). } \\
\text { Além do Ensino Fundamental obrigatório, a CF fixou a "progressiva exten- } \\
\text { são da obrigatoriedade e gratuidade ao ensino médio"; o "atendimento em } \\
\text { creche e pré-escola às crianças de zero a seis anos de idade"; o "atendi- } \\
\text { mento educacional especializado aos portadores de deficiência, prefe- } \\
\text { rencialmente na rede regular de ensino" e o "atendimento ao educando, } \\
\text { no ensino fundamental, através de programas suplementares de material } \\
\text { didático-escolar, transporte, alimentação e assistência à saúde." (Art. 208, } \\
\text { II, III e IV, VII) (BRASIL, 1988). Também estabeleceu a universalização do } \\
\text { Ensino Fundamental e a erradicação do analfabetismo como prioridades } \\
\text { para a década seguinte, fixando a aplicação de 50\% dos recursos vincula- } \\
\text { ção à educação no Art. } 212 \text { da Constituição Federal. A CF, no entanto, não } \\
\text { assumiu grandes compromissos com a universalização do ensino profis- } \\
\text { sional e superior ao não definir claramente as obrigações do Estado, pois } \\
\text { definiu vagamente entre os deveres do Estado com a educação o "acesso } \\
\text { aos níveis mais elevados do ensino, da pesquisa e da criação artística, } \\
\text { segundo a capacidade de cada um." (Art. 208, V) (BRASIL, 1988). }\end{array}$ \\
\hline $\begin{array}{l}\text { Emenda } \\
\text { Constitu- } \\
\text { cional n. } \\
\text { 14/1996 }\end{array}$ & $\begin{array}{l}\text { Em 1996, foi aprovada a Emenda Constitucional n. 14, que criou o } \\
\text { Fundo de Manutenção e Desenvolvimento do Ensino Fundamental e de } \\
\text { Valorização do Magistério (Fundef), vinculando 60\% dos recursos de } \\
\text { estados e municípios da educação ao Ensino Fundamental de que trata o } \\
\text { Art. } 212 \text { da CF. O Fundef substituiu a definição que determinava à União, } \\
\text { aos estados e os municípios a aplicação mínima de } 50 \% \text { dos recursos do } \\
\text { Art. } 212 \text { para "eliminar o analfabetismo e universalizar o ensino funda- } \\
\text { mental." Reduziu a obrigação da União de 50\% para 30\% e aumentou } \\
\text { a dos estados e municípios de 50\% para } 60 \% \text { dos } 25 \% \text { do Art. } 212 \text {, ou } \\
\text { seja, 15\% da receita de impostos. Em troca a União recebeu a atribuição } \\
\text { de aplicar 30\% dos recursos do Art. } 212 \text { e exercer a função "redistribu- } \\
\text { tiva" na complementação dos recursos do Fundef para garantir um valor } \\
\text { mínimo nacionalmente definido por aluno. O Fundef reduziu as respon- } \\
\text { sabilidades da União e aumentou a dos estados e municípios. Ao vincular } \\
\text { 15\% dos } 25 \% \text { do Art. } 212 \text { para essa finalidade, o Fundef criou dificul- } \\
\text { dades para os municípios financiarem a educação infantil e os estados, } \\
\text { financiarem o ensino médio (BRASIL, } 1988,1996 a, 2009 \text { ). }\end{array}$ \\
\hline
\end{tabular}




\begin{tabular}{|c|c|}
\hline $\begin{array}{l}\text { LDB } 1996 \\
\text { (Lei n. } \\
\text { 9.394/96) }\end{array}$ & 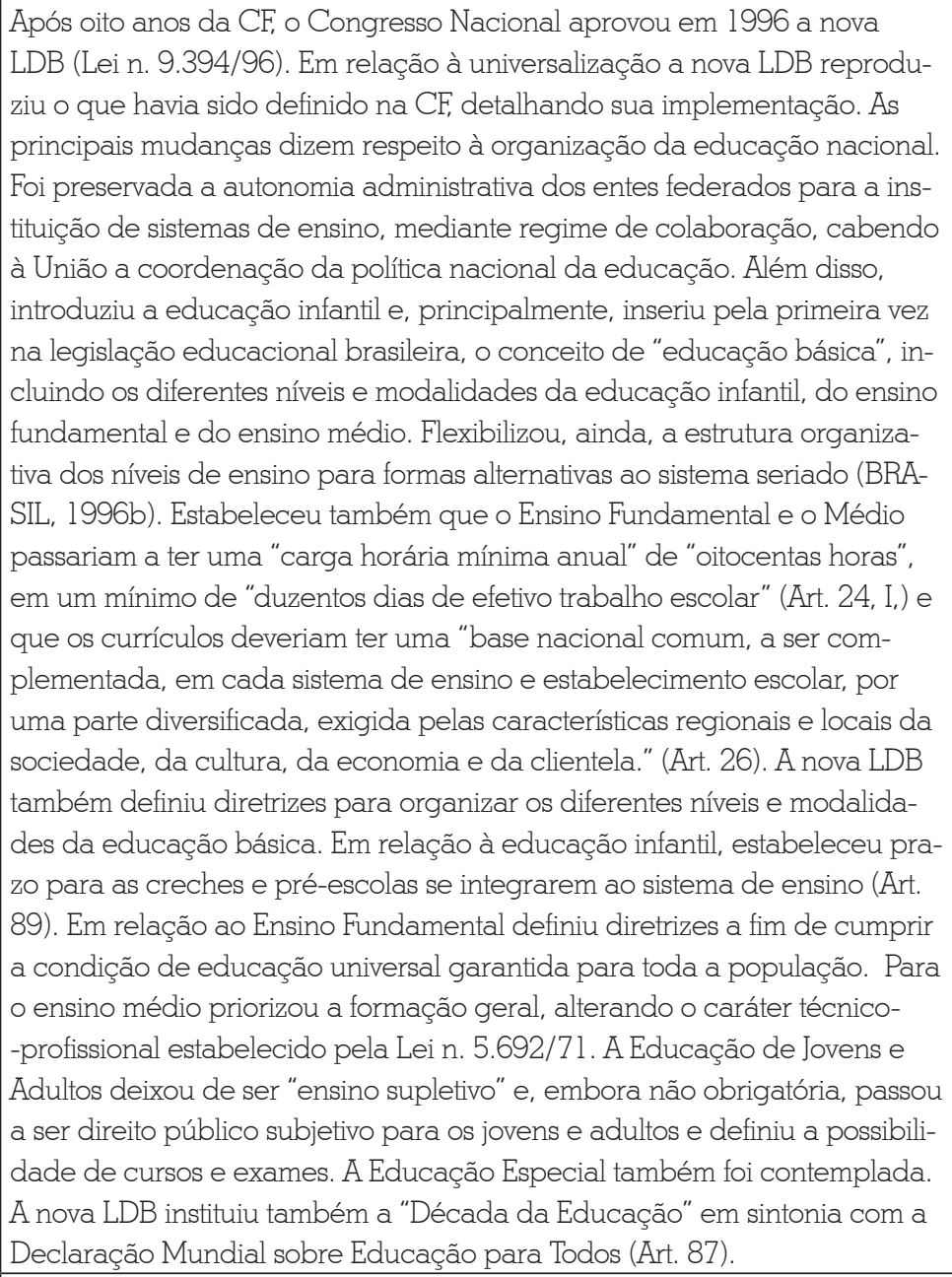 \\
\hline $\begin{array}{l}\text { Lei n. } \\
11.274 / 06\end{array}$ & $\begin{array}{l}\text { Em } 2006 \text { foi promulgada a Lei n. } 1 \text { 1.274, que altera a redação dos } \\
\text { Arts. 29, 30, } 32 \text { e } 87 \text { da Lei n. 9.394 da LDB, ficando estabelecida a } \\
\text { duração de nove anos para o Ensino Fundamental, com matrícula } \\
\text { obrigatória a partir dos seis anos de idade (BRASIL, 2006a). }\end{array}$ \\
\hline $\begin{array}{l}\text { Lei n. } \\
11.494 / 07\end{array}$ & $\begin{array}{l}\text { Promulgada em } 20 \text { de junho de 2007, a Lei n. } 11.494 \text { institui, no âmbito } \\
\text { de cada Estado e do Distrito Federal, um Fundo de Manutenção e De- } \\
\text { senvolvimento da Educação Básica e de Valorização dos Profissionais da } \\
\text { Educação (Fundeb), de natureza contábil, nos termos do Art. } 60 \text { do Ato } \\
\text { das Disposições Constitucionais Transitórias (ADCT) (BRASIL, 2007). }\end{array}$ \\
\hline $\begin{array}{l}\text { Lei n. } \\
11.378 / 08\end{array}$ & $\begin{array}{l}\text { Promulgada em } 16 \text { de julho de 2008, a referida Lei institui o piso salarial } \\
\text { profissional nacional aos professores do magistério público da educação } \\
\text { básica a que se refere a alínea "e" do inciso III do caput do art. } 60 \text { do Ato } \\
\text { das Disposições Constitucionais Transitórias (BRASIL, 2008a). }\end{array}$ \\
\hline
\end{tabular}




\begin{tabular}{|l|l|}
\hline EC 59/09 & $\begin{array}{l}\text { A Emenda Constitucional n. } 59 \text { dá nova redação aos incisos I e VII do Art. } \\
208 \text { da CF, estabelecendo a educação básica obrigatória e gratuita dos } 4 \\
\text { aos } 17 \text { anos de idade, assegurada inclusive sua oferta gratuita para todos } \\
\text { os que a ela não tiveram acesso na idade própria (BRASIL, 2009). }\end{array}$ \\
\hline $\begin{array}{l}\text { Lei } 12.796 / 13 \\
\text { A Lei n. 12.796/13 estabeleceu o acesso público e gratuito aos ensinos } \\
\text { fundamental e médio para todos os que não os concluíram na idade } \\
\text { própria. Ao Estado cabe garantir o acesso dos jovens e adultos aos } \\
\text { ensino fundamental e médio, conforme a procura dos interessados. } \\
\text { A Lei também alterou a LDB de 1996, ampliando as garantias para o } \\
\text { atendimento da educação infantil de 0 a 3 anos (BRASIL, 2013). }\end{array}$ \\
\hline \multirow{2}{*}{$\begin{array}{l}\text { A Lei n. 13.005/14 aprovou o Plano Nacional de Educação (2014-2024), } \\
\text { tendo como meta ampliar para 10\% do PIB o investimento público em } \\
\text { educação; estabelecer nova vinculação de recursos à educação; acres- } \\
\text { centar para além daqueles já vinculados pelo Art. 212 da CF os recursos } \\
\text { da "parcela da participação no resultado ou da compensação financeira } \\
\text { pela exploração de petróleo e de gás natural", incluindo os oriundos da } \\
\text { camada do "pré-sal", na forma da Lei n. 12.858/13 (BRASIL, 20l4). }\end{array}$} \\
\hline
\end{tabular}

Fonte: os autores.

Os novos marcos legais e os investimentos feitos nas últimas décadas, especialmente a partir de 2003, resultaram em importantes avanços no que tange à universalização da educação básica. Na década entre 2004 e 2013 , conforme dados da Tabela 4, a frequência escolar cresceu de 13\% para 23,2\% entre as crianças de 0 a 3 anos; de 61,5\% para 81,4\% na pré-escola de 4 a 5 anos; de 96,1\% para 98,4\% no ensino fundamental e de 81,8\% para 84,3\% no ensino médio. Nesse período houve uma elevação de $75 \%$ do tempo de educação escolar na condição de direito público subjetivo (dos 7 aos 14 anos para dos 4 aos 17 anos); em 78,5\% o percentual de atendimento em creches de 0 a 3 anos; em 32\% a taxa de frequência escolar na pré-escola de 4 a 5 anos; em 2,45\% no ensino fundamental de 6 a 14 anos e em 3\%, no ensino médio.

A Tabela 3 indica que a ampliação da universalização, nesse momento de mudança demográfica no Brasil, de deslocamento da bolha populacional da infância e juventude para a população adulta, não implica aumento de matrículas na educação básica. $\bigcirc$ aumento de matrículas ocorre nas duas pontas que ainda estão longe da universalização, na educação infantil de 0 a 3 anos e no ensino superior. 
Tabela 3 - Matrículas na educação básica e superior no período 1997-2013

\begin{tabular}{|c|c|c|c|}
\hline NÍVEIS & 1997 & 2005 & 2013 \\
\hline 1 Educação infantil de 0 a 3 anos em creches & 348.012 & 1.414 .343 & 2.730 .119 \\
\hline 2 Educação infantil Pré-escola* & 4.292 .208 & 5.790 .670 & 4.860 .481 \\
\hline 3 Ensino Fundamental ** & 35.656 .082 & 33.534 .561 & 29.069 .281 \\
\hline $\begin{array}{l}4 \text { Educação Especial em escolas e turmas } \\
\text { especiais }\end{array}$ & 334.507 & 378.074 & 194.421 \\
\hline $\begin{array}{l}\text { especlals } \\
\text { 4.1 Educação especial em classes comuns }\end{array}$ & - & 262.243 & 648.921 \\
\hline $\begin{array}{l}\text { População de } 7 \text { a } 14 \text { anos (1997 e 2005) e de } \\
6 \text { a } 14 \text { anos (2013) }\end{array}$ & 28.504 .797 & 27.578 .016 & 30.227 .810 \\
\hline $\begin{array}{l}\text { Matrículas do ensino fundamental em percen- } \\
\text { tual de crianças de } 7 \text { a } 14 \text { anos ( } 1997 \text { e 2005) } \\
\text { e de } 6 \text { a } 14 \text { anos (2013) }\end{array}$ & $126,26 \%$ & $122,97 \%$ & $96,81 \%$ \\
\hline $\begin{array}{l}\text { Frequência escolar na idade de } 7 \text { a } 14 \text { anos } \\
\text { (1997 e 2005) e de } 6 \text { a } 14 \text { anos (2013) }\end{array}$ & $95,0 \%$ & $96,8 \%$ & $98,4 \%$ \\
\hline 5 Ensino médio (3 anos) & 6.405 .057 & 9.031 .302 & 8.312 .815 \\
\hline 5. 1 Normal/Magistério & - & - & 120.218 \\
\hline $\begin{array}{l}5.2 \text { Integrado à Ed. Prot. Técnica de Nivel } \\
\text { Médio }\end{array}$ & - & - & 338.390 \\
\hline 6 Educação profissional e tecnológica (NI) & - & 707.263 & 1.102 .661 \\
\hline 7 Educação de Jovens e Adultos & 2.946 .670 & 5.615 .409 & 3.772 .670 \\
\hline 7.2 Semipresencial com avaliação no processo & 2.881 .770 & 4.619 .409 & 3.254 .510 \\
\hline 7.3 Cursos preparatórios para exames & & 996.000 & 456.697 \\
\hline 7.4 Integrada à Educação profissional e & 64.900 & - & - \\
\hline tecnológica & 36 & - & 61 \\
\hline $\begin{array}{l}8 \text { Total Educação Básica } \\
(1+2+3+4+5+6+7)\end{array}$ & 49.982 .536 & 56.471 .622 & 50.042 .448 \\
\hline 9 Ensino superior (graduação presencial) & 1.945 .615 & 4.453 .156 & 7.305.977 \\
\hline 10 Ensino superior (graduação) a distância & - & - & 1.153 .572 \\
\hline $\begin{array}{l}11 \text { Total de matrículas do ensino em geral } \\
(8+9)\end{array}$ & 51.928 .151 & 60.924 .778 & 58.501 .997 \\
\hline
\end{tabular}

Fonte: elaborada a partir dos dados extraídos das seguintes fontes: Instituto Nacional de Estudos e Pesquisas Educacionais Anísio Teixeira (1997, 2003a, 2005, 2015 e 2013) e IBGE (2013 e 2016).

* Pré-escola até 2005: 4, 5 e 6 anos; a partir de 2006: 4 e 5 anos.

** Ensino fundamental: até 2005 de 8 anos (7 a 14 anos); a partir de 2006 de 9 anos (6 a 14 anos).

A Tabela 4 apresenta a evolução da frequência escolar nos diversos níveis de ensino nos anos 2004 e 2013 e uma correlação com as metas estabelecidas pelo atual Plano Nacional de Educação (PNE) para o ano 2024. 


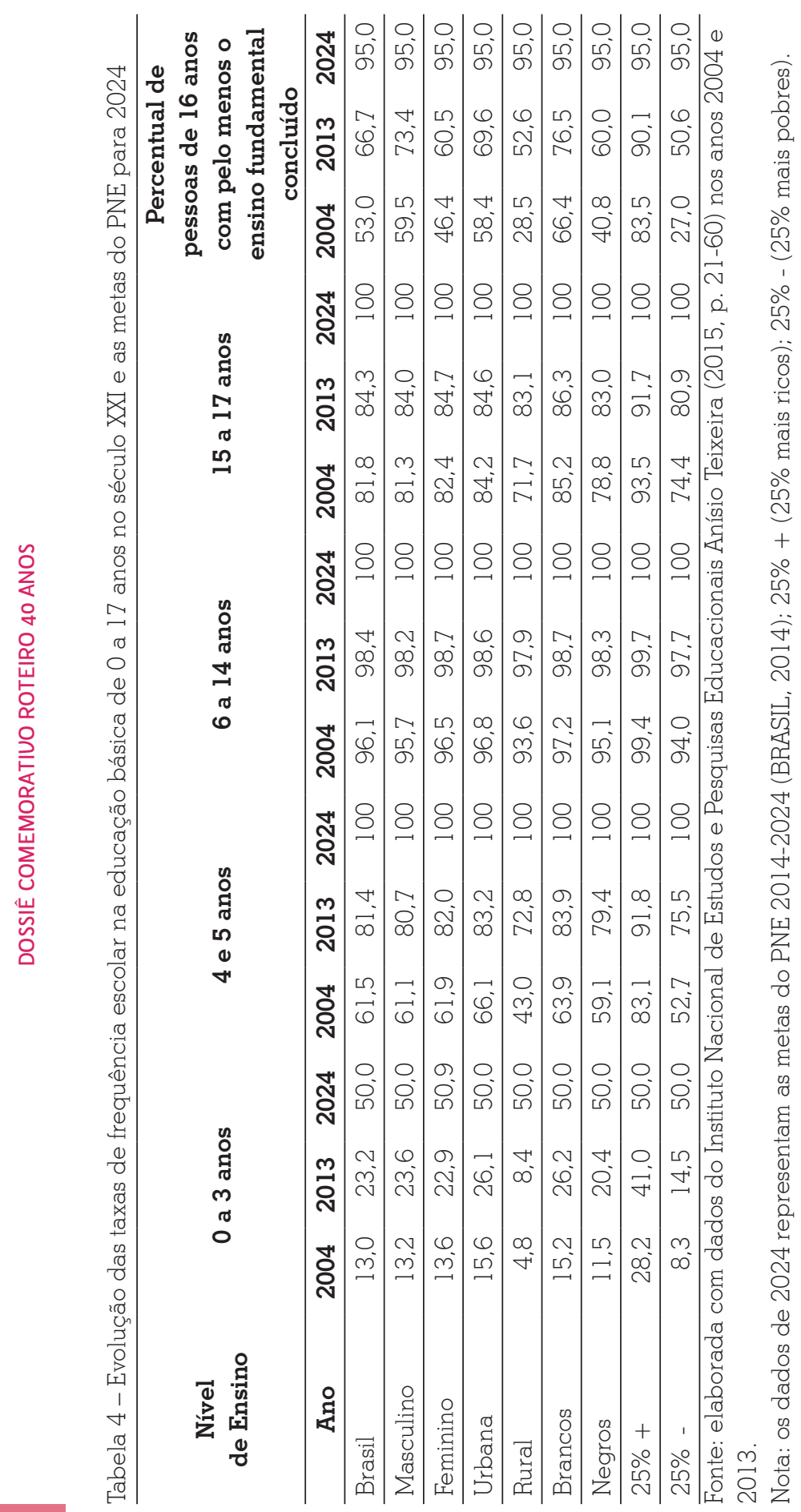


Nesses dados chamam particularmente a atenção as disparidades e as desigualdades entre etnias e renda. As mais evidentes estão entre brancos e negros e entre os mais ricos e os mais pobres. Em 2013, no grupo dos 25\% mais pobres, apenas $50,6 \%$ dos jovens de 16 anos concluíram o ensino fundamental, enquanto entre os mais ricos o percentual é de $90,1 \%$. Similar desigualdade se verifica entre negros e brancos. Enquanto $76,5 \%$ dos brancos concluíram esse nível de ensino, o percentual de negros é de 60\%. São as crianças dos ricos que mais frequentam as escolas de 4 e 5 anos (92\%). O percentual entre os $25 \%$ mais ricos e os $25 \%$ mais pobres é de $75 \%$. De acordo com dados recentes do IBGE (2017), a taxa de analfabetismo em 2016 era de $7,2 \%$, sendo que o percentual de analfabetos entre negros $(9,9 \%)$ é mais que o dobro do de pessoas brancas $(4,2 \%)$. As desigualdades demonstram que os desafios da universalização não são pequenos e vão muito além do acesso à escola; precisa-se articular políticas públicas de acesso, permanência, aprendizagem e conclusão dos níveis de ensino.

Em 2024, de acordo com as projeções do IBGE (2013), o Brasil terá cerca de 51,5 milhões de crianças, adolescentes e jovens entre 0 e 17 anos. Para atingir as metas do PNE para 2024 (universalizar a educação básica de 4 a 17 anos e atender a 50\% das crianças de 0 a 3 anos) será necessária a oferta de 45,8 milhões de matrículas. Confirmadas as projeções do IBGE, o Brasil não terá nos próximos anos uma pressão para a abertura de escolas. As mudanças na demografia do País (redução das taxas de natalidade e aumento da expectativa de vida) e a melhora no fluxo escolar estabilizarão a demanda por vagas de matrículas. Em 2005 o Brasil ofertou 50,8 milhões de matrículas, e em 2013, 46,3 milhões. Os sistemas de ensino já ofertam as vagas necessárias para atender à demanda projetada para 2024. Universalizado o acesso, permanecem outros tantos desafios, como a qualidade do ensino, a redução das desigualdades entre regiões, grupos sociais e renda, a formação continuada de professores, a inovação e a redução da evasão e das distorções idade-série. 


\section{CONSIDERAÇÕES FINAIS}

Como demonstrado ao longo deste artigo e sintetizado no Quadro a seguir, a universalização da educação básica no Brasil foi lenta e tardia. A instrução primária, com duração de 2 a 5 anos, foi estruturada a partir de 1920 mediante as reformas estaduais. A escolaridade mínima obrigatória de 8 anos foi estabelecida somente em 1971 (Lei n. 5.692); a de 9 anos em 2006 (Lei n. 11.274) e a de 14 anos (dos 4 aos 17 anos de idade, envolvendo a educação básica, inclusive para os jovens e adultos que não tiveram acesso na idade própria) em 2009 (EC n. 59). A partir de 2016, a educação básica de 4 a 17 anos passou a ser obrigatória e gratuita. A despeito de o Estado brasileiro ter reconhecido a educação como um direito social na década de 1930, foi somente em 1988 que o ensino obrigatório foi assumido pela Constituição como um direito público subjetivo.

Quadro 3 - Síntese do processo de universalização da educação básica no Brasil (1500-2016)

\begin{tabular}{|c|c|}
\hline Períodos & Dimensões da universalização \\
\hline $\begin{array}{l}\text { Brasil Co- } \\
\text { lônia } \\
\text { (1500-1822) }\end{array}$ & $\begin{array}{l}\text { Ensino público inexistente. Os Colégios Jesuítas viabilizaram a educa- } \\
\text { ção dos filhos da aristocracia e a formação do clero. O analfabetismo } \\
\text { das pessoas de } 15 \text { anos ou mais era de cerca de 99\% (GOMES, 2010, } \\
\text { p. 215). }\end{array}$ \\
\hline $\begin{array}{l}\text { Império } \\
\text { 1822-1889 }\end{array}$ & $\begin{array}{l}\text { Embora a Constituição de } 1824 \text { garantisse "instrucção primaria, e } \\
\text { gratuita a todos os cidadãos" (Art. 179, XXXII) (BRASIL, 1824) o acesso } \\
\text { continuou sendo um privilégio. Em 1884, as matrículas do ensino } \\
\text { primário correspondiam a 13\% da população de crianças de } 7 \text { a } 12 \\
\text { anos (IBGE, 2006b, p. 1, 2006a, p. 1). Cerca 84\% da população era } \\
\text { analfabeta em } 1887 \text { (CARVALHO, 2014, p. 24). }\end{array}$ \\
\hline $\begin{array}{l}\text { Primeira } \\
\text { República } \\
\text { 1889-1929 }\end{array}$ & $\begin{array}{l}\text { A Constituição Republicana de } 1891 \text { não inseriu qualquer direito à } \\
\text { educação. Desde o Ato Adicional de } 1834 \text { a educação primária estava } \\
\text { a cargo das províncias (estados). Cada unidade da federação organi- } \\
\text { zava seu ensino primário, que variava de } 2 \text { a } 5 \text { anos de ensino gratuito } \\
\text { (ROMANELLI, 2014, p.130; NAGLE, 2009, p. 226-233). As matrículas } \\
\text { do ensino primário em } 1929 \text { correspondiam a 35\% da população de } \\
\text { crianças de } 7 \text { a } 12 \text { anos (NAGLE, 2009, p. 314; IBGE, 2006a, p. 1). } \\
\text { Cerca de 65\% eram analfabetas (INSTITUTO NACIONAL DE ESTU- } \\
\text { DOS E PESQUISAS EDUCACIONAIS ANÍSIO TEIXEIRA, 2003a, p. 6). }\end{array}$ \\
\hline
\end{tabular}




\begin{tabular}{|c|c|}
\hline $\begin{array}{l}\text { Ditadura } \\
\text { Vargas } \\
\text { 1930-1945 }\end{array}$ & $\begin{array}{l}\text { Em } 1945 \text { as matrículas no ensino primário atingiam cerca de 45\% das } \\
\text { crianças de } 7 \text { a } 12 \text { anos (IBGE, 2006b, p. 1; INSTITUTO NACIONAL } \\
\text { DE ESTUDOS E PESQUISAS EDUCACIONAIS ANÍSIO TEIXEIRA, 1987, } \\
\text { p. 155- 163). A despeito da Constituição de } 1934 \text { ter garantido "ensino } \\
\text { primário integral gratuito e de frequência obrigatória extensivo aos } \\
\text { adultos" (Art. 150, § único, c) (BRASIL, 1934), em } 1940 \text { o analfabe- } \\
\text { tismo era de cerca 56, 1\% (INSTITUTO NACIONAL DE ESTUDOS E } \\
\text { PESQUISAS EDUCACIONAIS ANÍSIO TEIXEIRA, 2003a, p. 6). }\end{array}$ \\
\hline $\begin{array}{l}\text { Redemocra- } \\
\text { tização } \\
\text { 1945-1964 }\end{array}$ & $\begin{array}{l}\text { A LDB de } 1961 \text { definiu o ensino primário de, no mínimo, } 4 \text { séries anu- } \\
\text { ais, a partir dos } 7 \text { anos (BRASIL (196l) (Arts. 26-27). Em } 1964 \text { o Brasil } \\
\text { alcançou 66, } 14 \% \text { de frequência escolar de } 7 \text { a } 11 \text { anos (ROMANELLI, } \\
\text { 2014, p. 85), com taxa de analfabetismo de cerca de 39,7\% (INSTITU- } \\
\text { TO NACIONAL DE ESTUDOS E PESQUISAS EDUCACIONAIS ANÍSIO } \\
\text { TEIXEIRA, 2003, p. 6). }\end{array}$ \\
\hline $\begin{array}{l}\text { Ditadura } \\
\text { Militar } \\
\text { 1964-1984 }\end{array}$ & $\begin{array}{l}\text { A Constituição de } 1967 \text { e a LDB de } 1971 \text { definiram "o ensino obri- } \\
\text { gatório e gratuito dos } 7 \text { aos } 14 \text { anos." A frequência escolar no ensino } \\
\text { gratuito e obrigatório correspondia a } 85 \% \text { em } 1985 \text { (GERMANO, } 201 \text { l, } \\
\text { p. 169). Em } 1980 \text { o analfabetismo era de cerca de 25,9\% (INSTITU- } \\
\text { TO NACIONAL DE ESTUDOS E PESQUISAS EDUCACIONAIS ANÍSIO } \\
\text { TEIXEIRA, 2003a, p. 6). }\end{array}$ \\
\hline $\begin{array}{l}\text { Redemocra- } \\
\text { tização } \\
1985-2016\end{array}$ & $\begin{array}{l}\text { A Constituição de } 1988 \text { estabeleceu como direito público subjetivo } \\
\text { o ensino fundamental de } 8 \text { anos (obrigatório e gratuito), extensivo } \\
\text { aos que não tiveram acesso na idade própria. As Leis posteriores (n. } \\
\text { 9.394/96, n. 1 1.274/06, n. 1 1.494/07, n. } 1 \text { 1.378/08 e n. 12.796/13) e } \\
\text { a Emenda Constitucional n. 59/09 regulamentaram aspectos impor- } \\
\text { tantes do Texto Constitucional e inseriram políticas de expansão da } \\
\text { educação básica. Em } 2013 \text { a frequência escolar atingiu 81,4\% das } \\
\text { crianças de } 4 \text { e } 5 \text { anos da pré-escola; 98,4\% das crianças de } 6 \text { a } 14 \\
\text { anos e 84,3\% dos jovens do ensino médio. Nesse mesmo ano o analfa- } \\
\text { betismo atingiu 8,5\% e o analfabetismo funcional, 29,4\% da população } \\
\text { de } 15 \text { anos ou mais (INSTITUTO NACIONAL DE ESTUDOS E PESQUI- } \\
\text { SAS EDUCACIONAIS ANÍSIO TEIXEIRA, 2015, p. 25, 42 e 56). } \\
\end{array}$ \\
\hline
\end{tabular}

Fonte: os autores.

Os limites destacados ao longo deste artigo não podem deixar de reconhecer que o Brasil, nos últimos 80 anos, "abriu os portões" da escola pública para um gigantesco contingente populacional. Trata-se de uma revolução silenciosa que promoveu a difusão e a consolidação da escola pública de massa no País e sua conquista pelo povo. A escola pública estatal se tornou a escola popular das massas. Os avanços não teriam ocorrido sem a responsabilização do Estado brasileiro pelo direito social à educação e 
pelo direito público subjetivo. A trajetória da universalização reflete o próprio processo de construção dos direitos de cidadania num país em que a escravidão foi, por quase quatro séculos, pilar de uma sociedade desigual e autoritária e de um Estado oligárquico a serviço das elites.

\section{REFERÊNCIAS}

ARAÚJO, M. M. de. O debate sobre a escolarização primária organizada pela lei imperial de 1827 e reorganizada pelo ato adicional de 1834 . Rio Grande do Norte: Ed. UFRN, 2002. Disponível em: < http://www.afirse.com/ archives/cd3/tematica2/039.pdf>. Acesso em: 15 maio 2016.

AZEVEDO, F. de et al. Manifestos dos pioneiros da educação nova (1932) e dos educadores 1959. Recife: Fundação Joaquim Nabuco/Ed. Massangana, 2010. Disponível em: <http://www.dominiopublico.gov.br/download/texto/ me4707.pdf>. Acesso em: 18 jan. 2018.

BRASIL. Constituição Política do Império do Brazil de 1824: CLBR. Rio de Janeiro, DF, 1824. Disponível em: <http://www.planalto.gov.br/ccivil_03/ Constituicao/Constituicao24.htm>. Acesso em: 05 dez. 2014.

BRASIL. Constituição da República dos Estados Unidos do Brasil de 1891 Rio de Janeiro: DOU, 24 fev. 1891. Disponível em: <http://www.planalto.gov. br/ccivil_03/Constituicao/Constituicao9l.htm>. Acesso em: 05 dez. 2014.

BRASIL. Constituição da República dos Estados Unidos do Brasil de 1934. Rio de Janeiro: DOU, 1934. Disponível em: <http://www.planalto.gov.br/ccivil_03/Constituicao/Constituicao34.htm>. Acesso em: 05 dez. 2014.

BRASIL. Constituição dos Estados Unidos do Brasil de 1937. Rio de Janeiro: DOU, 1937, republicado em 18 nov. 1937 e 19 nov. 1937. Disponível em: <http://www.planalto.gov.br/ccivil_03/Constituicao/Constituicao37.htm >. Acesso em: 05 dez. 2014.

BRASIL. Constituição dos Estados Unidos do Brasil de 1946. Rio de Janeiro: DOU, 19 set. 1946, republicado em 25 set. 1946. Disponível em: < http:// www.planalto.gov.br/ccivil_03/Constituicao/Constituicao46.htm>. Acesso em: 05 dez. 2014.

BRASIL. Constituição da República Federativa do Brasil de 1967. Diário Oficial da União, Brasília, DF, 1967. Disponível em: <http://www.planalto.gov. br/ccivil_03/Constituicao/Constituicao67.htm>. Acesso em: 05 dez. 2014. 
BRASIL. Constituição da República Federativa do Brasil de 1988: consolidada. Brasília, DF: DOU, 1988. Disponível em: < http://www.planalto.gov.br/ ccivil_03/Constituicao/Constituicao.htm>. Acesso em: 02 jul. 2015.

BRASIL. Emenda Constitucional n. 14, de 12 de setembro de 1996. Modifica os arts. 34, 208, 211 e 212 da Constituição Federal e dá nova redação ao art. 60 do Ato das Disposições constitucionais Transitórias. Diário Oficial da União, Brasília, DF, 12 set. 1996a. Disponível em: <http://www.planalto.gov. $\mathrm{br} / \mathrm{ccivil}$ 03/Constituicao/Emendas/Emc/emcl4.htm>. Acesso em: 02 jul. 2015.

BRASIL. Emenda Constitucional n. 59, 11 de novembro de 2009. Acrescenta § $3^{\circ}$ ao art. 76 do Ato das Disposições Constitucionais Transitórias para reduzir, anualmente, a partir do exercício de 2009, o percentual da Desvinculação das Receitas da União incidente sobre os recursos destinados à manutenção e desenvolvimento do ensino de que trata o art. 212 da Constituição Federal, [...] e dá nova redação ao $\$ 4^{\circ}$ do art. 211 e ao $\$ 3^{\circ}$ do art. 212 e ao caput do art. 214, com a inserção neste dispositivo de inciso VI. Diário Oficial da União, Brasília, DF, 11 nov. 2009. Disponível em: <http://www.planalto.gov. br/ccivil_03/Constituicao/Emendas/Emc/emc59.htm>. Acesso em: 02 jul. 2015.

BRASIL. Lei de 15 de outubro de 1827. Da responsabilidade dos Ministros e Secretários de Estado e dos Conselheiros de Estado. Rio de Janeiro: CLBR, 1827. Disponível em: <http://www.planalto.gov.br/ccivil_03/leis/LIM/LIM-1510-1827.htm>. Acesso em: 12 maio 2016.

BRASIL. Lei n. 16, de 12 de agosto de 1834. Faz algumas alterações e addições á Constituição Politica do Imperio, nos termos da Lei de 12 de Outubro de 1832. Secretaria de Estado dos Negocios do Imperio, Rio de Janeiro, 21 ago. 1834. Disponível em: <http://www.planalto.gov.br/ccivil_03/leis/lim/ LIM16.htm>. Acesso em: 05 dez. 2014.

BRASIL. Lei n. 4.024, de 20 de dezembro de 1961. Fixa as Diretrizes e Bases da Educação Nacional. Diário Oficial da União, Brasília, DF, 28 dez. 1961. Disponível em: <http://www.planalto.gov.br/ccivil_03/Leis/L4024.htm>. Acesso em: 05 dez. 2014.

BRASIL. Lei n. 5.692, de 11 de agosto de 1971. Fixa as Diretrizes e Bases para o ensino de $1^{\circ}$ e $2^{\circ}$ graus, e dá outras providências. Diário Oficial da União, Brasília, DF, 11 ago. 1971. Disponível em: < http://www.planalto.gov.br/ccivil_03/Leis/L5692.htm>. Acesso em: 05 dez. 2014. 
BRASIL. Lei n. 9.394, de 20 de dezembro de 1996. Estabelece as diretrizes e bases da educação nacional. Diário Oficial da União, Brasília, DF, 20 dez. 1996b. Disponível em: <http://www.planalto.gov.br/ccivil_03/LEIS/L9394. htm>. Acesso em: 08 ago. 2015.

BRASIL. Lei n. 1 1.274, 06 de fevereiro de 2006. Altera a redação dos arts. 29, 30, 32 e 87 da Lei no 9.394, de 20 de dezembro de 1996, que estabelece as diretrizes e bases da educação nacional, dispondo sobre a duração de 9 (nove) anos para o ensino fundamental, com matrícula obrigatória a partir dos 6 (seis) anos de idade. Diário Oficial da União, Brasília, DF, 06 fev. 2006a. Disponível em: <http://www.planalto.gov.br/ccivil_03/_ato2004-2006/2006/ lei/ll 1274.htm>. Acesso em: 09 jan. 2016.

BRASIL. Lei n. 1 1.378, 2008. Regulamenta a alínea "e" do inciso III do caput do art. 60 do Ato das Disposições Constitucionais Transitórias, para instituir o piso salarial profissional nacional para os profissionais do magistério público da educação básica. Diário Oficial da União, Brasília, DF, 2008a. Disponível em: <http://www.planalto.gov.br/ccivil_03/_ato2007-2010/2008/ lei/ll 1738.htm>. Acesso em 09 jan. 2016.

BRASIL. Lei n. 1 1.494, 20 de junho de 2007. Regulamenta o Fundo de Manutenção e Desenvolvimento da Educação Básica e de Valorização dos Profissionais da Educação - FUNDEB [...] Diário Oficial da União, Brasília, DF, 20 jun. 2007. Disponível em: <http://www.planalto.gov.br/ccivil_03/_ato20072010/2007/lei/l1 1494.htm>. Acesso em: 09 jan. 2016.

BRASIL. Lei n. 12.796, 04 de abril de 2013. Altera a Lei n 9.394, de 20 de dezembro de 1996, que estabelece as diretrizes e bases da educação nacional, para dispor sobre a formação dos profissionais da educação e dar outras providências. Diário Oficial da União, Brasília, DF, 04 abr. 2013. Disponível em: <http://www.planalto.gov.br/ccivil_03/_ato201 1-2014/2013/lei/112796. htm>. Acesso em: 08 ago. 2015.

BRASIL. Lei n. 13.005, 25 de junho de 2014. Aprova o Plano Nacional de Educação - PNE e dá outras providências. Diário Oficial da União, Brasília, DF, 25 jun. 2014. Disponível em: < http://www.planalto.gov.br/ccivil_03/_ ato201 1-2014/2014/lei/113005.htm>. Acesso em: 08 ago. 2015.

CARVALHO, J. M. de. Cidadania no Brasil. O longo caminho. 18. ed. Rio de Janeiro: Civilização Brasileira, 2014.

CHAUI, M. Mito fundador e sociedade autoritária. 1. ed. São Paulo: Fundação Perseu Abramo, 2000. 
DUARTE, C. S. Direito público subjetivo e políticas educacionais. São Paulo em Perspectiva, n. 18, n. 2, p. 113-118, 2004.

FREITAS, M. C.; BICCAS, M. de S. História social da educação no Brasil (1926-1996). São Paulo: Cortez, 2009.

GERMANO, J. W. Estado militar e educação no Brasil (1964-1985). 5. ed. São Paulo: Cortez, 2011.

GHIRALDELLI JÚNIOR, P. História da educação. 4. ed. São Paulo: Cortez, 1995.

GOMES, L. 1822: como um homem sábio, uma princesa triste e um escocês louco por dinheiro ajudaram D. Pedro a criar o Brasil - um país que tinha tudo para dar errado. Rio de Janeiro: Nova Fronteira, 2010.

GOMES, L. 1889: como um imperador cansado, um marechal vaidoso e um professor injustiçado contribuíram para o fim da monarquia e a proclamação da república no Brasil. 1. ed. São Paulo: Globo, 2013.

IBGE. Estatísticas do Século XX. Rio de Janeiro, 2006a. Disponível em: $<$ http://biblioteca.ibge.gov.br/visualizacao/monografias/GEBIS\%20-\%20RJ/ seculoxx.pdf>. Acesso em: 09 jan. 2016.

IBGE. Estatísticas do Século XX. Educação. População presente, segundo o sexo, os grupos de idade, o estado conjugal, a religião, a nacionalidade e a alfabetização - 1872-1991. Rio de Janeiro, 2006b. Disponível em: <http:// seculoxx.ibge.gov.br/images/seculoxx/arquivos_download/populacao/1994/ populacaol994aeb_01.pdf>. Acesso em 16. jan. 2016.

IBGE. Estatísticas do Século XX. Ensino primário geral (síntese) -

1871/1938. Rio de Janeiro, 2006c. Disponível em: http://seculoxx.ibge. gov.br/images/seculoxx/arquivos_download/educacao/1939_40/ educacaol939_40aeb_382_l.pdf >. Acesso em 16 jan. 2016.

IBGE. Estatísticas do Século XX. Educação. Ensino primário geral - 1933/57. Rio de Janeiro, 2006d. Disponível em: <http://seculoxx.ibge.gov.br/images/ seculoxx/arquivos_download/educacao/1960/educacaol960bn_0la02. pdf $>$. Acesso em $\overline{1} 6$ jan. 2016.

IBGE. Estatísticas do Século XX. Educação. Matrícula inicial no ensino de $1^{\circ}$ Grau, por dependência administrativa, segundo as unidades da federação - 1986-88. Rio de Janeiro, 2006e. Disponível em: < http://seculoxx.ibge. gov.br/images/seculoxx/arquivos_download/educacao/1990/educacao1990aeb_15.pdf>. Acesso em 16 jan. 2016. 
IBGE. País tem 1 1,8 milhões de analfabetos; taxa entre negros dobra ante brancos. Jornal Folha de S. Paulo, 21 dez. 2017. Educação. Disponível em: <wwwl.folha.uol.com.br>. Acesso em: 21 dez. 2017.

IBGE. Projeção da População do Brasil por sexo e idade: 2000-2060: 2013. Rio de Janeiro, 2013. Disponível em: <http://www.ibge.gov.br/home/estatisti$\mathrm{ca} /$ populacao/projecao_da_populacao/2013/default_tab.shtm > . Acesso em: 13 ago. 2016.

IBGE. Reprojeção da População do Brasil por sexo e grupo de idade 2000-1980. Rio de Janeiro, 2016b. Disponível em: <http://www.ibge. gov.br/home/estatistica/populacao/projecao_da_populacao/retroprojecao_2000_1980/default_tab.shtm>. Acesso em: 23 out. 2016.

IBGE. Síntese dos Indicadores Sociais 2003. Rio de Janeiro, 2003. Disponível em: <http://www.observatoriodegenero.gov.br/eixo/indicadores/publicacoes/sintese-dos-indicadores-sociais-2003-ibge>. Acesso em: 25 ago. 2016.

INSTITUTO NACIONAL DE ESTUDOS E PESQUISAS EDUCACIONAIS ANÍSIO TEIXEIRA. A educação no Brasil na década de 90: 1991-2000. Brasília, DF, 2003a.

INSTITUTO NACIONAL DE ESTUDOS E PESQUISAS EDUCACIONAIS ANÍSIO TEIXEIRA. Mapa do analfabetismo no Brasil. 2003b. Disponível em: < http:// www.inep.gov.br/estatisticas/analfabetismo/default.htm>. Acesso em: 03 set. 2016.

INSTITUTO NACIONAL DE ESTUDOS E PESQUISAS EDUCACIONAIS ANÍSIO TEIXEIRA. Plano Nacional de Educação PNE 2014-2024: Linha de Base. Brasília, DF, 2015. Disponível em: <http://www.publicacoes.inep.gov.br/portal/download/1362>. Acesso em: 10 jan. 2016.

INSTITUTO NACIONAL DE ESTUDOS E PESQUISAS EDUCACIONAIS ANÍSIO TEIXEIRA. Sinopse Estatística da Educação Básica 1997. Brasília, DF, 1997. Disponível em: <http://portal.inep.gov.br/basica-censo-escolar-sinopse-sinopse >. Acesso em: 23 jan. 2016.

INSTITUTO NACIONAL DE ESTUDOS E PESQUISAS EDUCACIONAIS ANÍSIO TEIXEIRA. Sinopse Estatística da Educação Básica 2005. Brasília, DF, 2005. Disponível em: <http://portal.inep.gov.br/basica-censo-escolar-sinopse-sinopse >. Acesso em: 23 jan. 2016. 
INSTITUTO NACIONAL DE ESTUDOS E PESQUISAS EDUCACIONAIS ANÍSIO TEIXEIRA. Sinopse Estatística da Educação Básica 2013. Brasília, DF, 2013.

Disponível em: <http://portal.inep.gov.br/basica-censo-escolar-sinopse-sinopse >. Acesso em: 23 jan. 2016.

MARSHALL, T. H. Cidadania, classe social e status. Rio de Janeiro: Zahar, 1967.

MAZZIONI, L. O Plano Nacional de Educação e o papel dos Municípios na universalização da educação básica no Brasil. 2016. 314 p. Dissertação (Mestrado em Educação)-Universidade Federal da Fronteira Sul, Chapecó, 2016. Disponível em: <https://rd.uffs.edu.br/bitstream/prefix/677/l/MAZZIONI.pdf>. Acesso em: 20 jan. 2018.

NAGLE, J. Educação e sociedade na primeira república. 3. ed. São Paulo: EDUSP, 2009.

ORGANIZAÇÃO DAS NAÇÕES UNIDAS. Declaração Universal dos Direitos Humanos. 2008. Disponível em: < https://www.unicef.org/brazil/pt/resources_10l33.htm>. Acesso em: 20 jun. 2018.

RIBEIRO, D. O povo brasileiro. A formação e o sentido do Brasil. 3. ed. São Paulo: Companhia das Letras, 2013.

ROMANELLI, O. História da educação no Brasil. 40. ed. Petrópolis: Vozes, 2014.

SAVIANI, D. História das ideias pedagógicas no Brasil. 4. ed. Campinas: Autores Associados, 2013.

SCHNEIDER, E. M.; MEGLHIORATTI, F. A. A influência do movimento eugênico na constituição do sistema organizado de educação pública do Brasil na década de 1930. In: ANPED SUL, 9., 2012, Caxias do Sul. Anais... Caxias do Sul, 2012. Disponível em: <http://www.ucs.br/etc/conferencias/index.php/ anpedsul/9anpedsul/paper/viewFile/963/ > . Acesso em: 15 dez. 2014.

SOUZA, R. F. de. História da organização do trabalho escolar e do currículo no século XX. São Paulo: Cortez, 2008.

Recebido em 31 de janeiro de 2018 Aceito em 04 de julho de 2018

Endereços para correspondência: Avenida Fernando Machado, 108E, Centro, 89814-470, Chapecó, Santa Catarina, Brasil; joviles.trevisol@uffs.edu.br 
